\title{
Commentary: There's bacteria in them thar valves
}

\author{
Frank A. Baciewicz, Jr, MD
}

\footnotetext{
From the Department of Cardiothoracic Surgery, Michael and Marian Ilitch Department of Surgery, Wayne State University School of Medicine, Detroit, Mich.

Disclosures: Author has nothing to disclose with regard to commercial support.

Received for publication Feb 23, 2019; accepted for publication Feb 25, 2019; available ahead of print April 9, 2019.

Address for reprints: Frank A. Baciewicz, Jr, MD, Department of Cardiothoracic Surgery, Michael and Marian Ilitch Department of Surgery, Wayne State University School of Medicine, Harper Hospital, 3990 John R, Suite 2102, Detroit, MI 48201 (E-mail: fbaciewi@dmc.org).

J Thorac Cardiovasc Surg 2020;159:125-6

$0022-5223 / \$ 36.00$

Copyright (C) 2019 by The American Association for Thoracic Surgery

https://doi.org/10.1016/j.jtcvs.2019.02.117
}

\begin{abstract}
Although not the "There's gold in them thar hills" penned in Mark Twain's 1892 novel The American Claimant, ${ }^{1}$ Oberbach and colleagues ${ }^{2}$ make the provocative, possibly treatment-altering discovery that bacteria are prevalent in calcified heart valves. The authors employed primarily a metagenomic methodology to demonstrate bacterial organisms in 14 out of 25 randomly selected calcific aortic/mitral valves that had been excised during valve replacement. Those valve replacements were not performed for endocarditis, and all patients had negative preoperative blood cultures.
\end{abstract}

Many cardiac surgeons, including myself, have been surprised when excised nonendocarditic valve material is noted to test positive for bacteria, either on pathology report or valve culture. Oberbach and colleagues ${ }^{2}$ sonified the excised calcified valve material, which was then cultured, and applied metagenomic analysis of DNA to detect bacteria in 14 out of 25 valves. This seems an extremely high percentage of valves harboring bacteria, but any skepticism was overwhelmed by understanding that the metagenomic technique can detect as little as $0.1 \%$ to $0.27 \%$ of calcified material as nonhuman DNA. Gene sequences of only 96 to 590 are enough to identify that the nonhuman DNA is from a specific bacterial organism. This number may underestimate the prevalence of bacteria present in calcified valves when one appreciates that not all bacterial strains have an identified DNA signature.

The idea that bacteria contribute to structural valve calcification is not entirely novel. The presence of bacteria in calcified heart valves was first demonstrated by Kolltveit and colleagues ${ }^{3}$ in 2002 . Previous investigators, including Giladi and colleagues, ${ }^{4}$ Chuard and colleagues, ${ }^{5}$ and Campbell and colleagues, ${ }^{6}$ noted bacteria in structural heart valves, but assumed they were contaminants. Cohen and colleagues ${ }^{7}$ conducted an elegant laboratory study showing that injecting bacteria in rabbits resulted in calcified aortic valves.

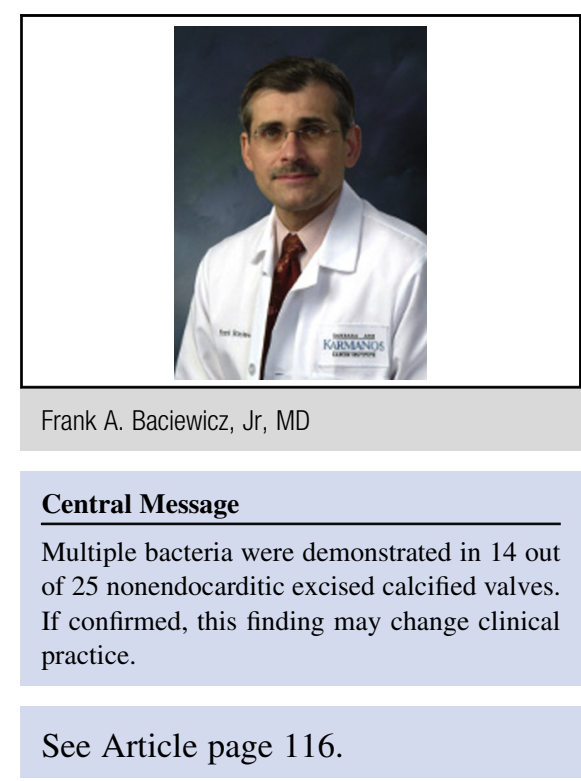

The metagenomic technique needs to be applied to a larger group of patients at multiple sites. If the findings are supported, the practice of leaving calcium behind with rapid deployment valves may change. The transcatheter valve replacement population has a higher than expected (1.7\%-2.3\%) 1-year endocarditis rate. ${ }^{8,9}$ The higher than expected endocarditis rate could be explained by the transcatheter valve replacement techniques of balloon inflation to seat the aortic valve, balloon valvuloplasty before deployment, or dilatation of the implanted valve to decrease paravalvular leak that could fracture the aortic valve calcium and release dormant bacteria. If the data presented by Oberbach and colleagues ${ }^{2}$ are confirmed, techniques of limited decalcification during mitral valve replacement may have to be revised.

In addition, treatment of patients who develop or have calcified valves (eg, those with renal failure, women with diabetes with calcified mitral valves, transplant patients, and patients taking immunosuppressive drugs) may require revision. Could calcification of prosthetic biologic prosthesis or mechanical valve pannus be partially accounted for by subclinical bacteremia? Should patients with calcific valves who undergo replacement or have bacteria noted on postoperative analysis receive an extended antibiotic protocol? Certainly the authors awake a slew of thoughtprovoking scenarios and possible alterations in treatment strategies. 
Among the 25 studied valves, 1 was mitral. Why was only 1 mitral valve selected for study? Future studies will need to study both aortic and mitral valves.

Eight out of 14 patients with bacteria-positive valves had 2 or more organisms detected. The authors suggest that multibacterial colonization may be the trigger for calcific heart valve changes. It is unclear how this multibacterial colonization fits into the spectrum of standard endocarditis. The data showing valves with multibacterial organisms are further confusing because the microbiologic-/histologic-detected bacteria differ from the microorganisms demonstrated by metagenomic analysis on the same valve. In other words, the offending organisms differed depending on the method of detection. What is the explanation?

The protagonists in Mark Twain's novel were not successful in prospecting for gold in them thar hills. ${ }^{1}$ Hopefully, future endeavors by Oberbach and colleagues ${ }^{2}$ will strike gold by clarifying these provocative initial findings and establishing a treatment protocol for patients with calcific valve disease.

\section{References}

1. Twain M. The American Claimant. New York: Charles L. Webster and Co; 1892. 2. Oberbach A, Friedrich M, Lehmann S, Schlichting N, Kullnick Y, Graber S, et al. Bacterial infiltration in structural heart valve disease. J Thorac Cardiovasc Surg. 2020;159:116-24.e4.

3. Kolltveit KM, Geiran O, Tronstad L, Olsen I. Multiple bacteria in calcific aortic valve stenosis. Microbial Ecol Health Dis. 2002;14:110-7.

4. Giladi M, Szold O, Elami A, Bruckner D, Johnson BL Jr. Microbiological cultures of heart valves and valve tags are not valuable for patients without infective endocarditis who are undergoing valve replacement. Clin Infect Dis. 1997:24:884-8.

5. Chuard C, Antley CM, Reller LB. Clinical utility of cardiac valve gram stain and culture in patients undergoing native valve replacement. Arch Pathol Lab Med. 1998; 122:412-5.

6. Campbell WN, Tsai W, Mispireta LA. Evaluation of the practice of routine culturing of native valves during valve replacement surgery. Ann Thorac Surg. 2000;69:548-50.

7. Cohn DJ, Malave D, Ghidoni JJ, Iakovidis P, Everett MM, You S, et al. Role of oral bacterial flora in calcific aortic stenosis: an animal model. Ann Thorac Surg. 2004; 77:537-43.

8. Kolte D, Goldsweig A, Kennedy KF, Abbott JD, Gordon PC, Sellke FW, et al. Comparison of incidence, predictors, and outcomes of early infective endocarditis after transcatheter aortic valve implantation versus surgical aortic valve replacement in the United States. Am J Cardiol. 2018;122:2112-9.

9. Ando T, Ashraf S, Villablanca PA, Tellia TA, Takagi H, Grines CL, et al. Metaanalysis comparing the incidence of infective endocarditis following transcatheter aortic valve implantation versus surgical aortic valve replacement. Am J Cardiol. 2019;123:827-32. 